\title{
7. SEDIMENTARY AND METAMORPHIC ROCK CLASTS FROM THE CENOZOIC DIAMICTONS OF SITES 739-743, PRYDZ BAY, EAST ANTARCTICA ${ }^{1}$
}

\author{
C. J. Jenkins ${ }^{2}$ and C. Alibert ${ }^{3}$
}

\begin{abstract}
Petrographic studies of clasts in the glacial diamictons of Prydz Bay indicate that the predominant ice supply was from the Lambert Glacier (Prince Charles Mountains and Lambert Graben regions); no compelling evidence is seen for clastic supply from the Vestfold Hills and Larsemann Hills areas. The clasts also reveal the presence in East Antarctica of (1) an early Oligocene-late Eocene (34-36 Ma) diatomaceous marine marl facies and (2) a Jurassic-Cretaceous sandy limestone lithofacies, possibly of subaerial origin.
\end{abstract}

\section{INTRODUCTION}

The glacial diamictons sampled by the Ocean Drilling Program (ODP) at Sites 739-743 in Prydz Bay range in age from Holocene to late Eocene-early Oligocene (Hambrey et al., 1989) and contain gravel in varying proportions between $0 \%$ and $22 \%$ (Barron, Larsen, et al., 1989). This study examined the nature of the gravel clasts with the dual aims of (1) establishing the sources of the ice that deposited the glaciomarine clastic rocks and (2) searching for evidence of geological units that may be hidden under ice, submerged, or buried in the region.

\section{Methods}

A representative selection of 160 clasts, ranging in size up to $7 \mathrm{~cm}$, was made from the cores recovered at Sites 739-743. The selected clasts were split (sawn) aboard ship, with one-half retained in the archive half of the core. Because most specimens were rendered incomplete by the drilling and splitting, no analysis of clast shape was undertaken. Post-cruise analysis involved description of the clasts' mesoscopic characters and the preparation of numerous petrographic thin sections. Metamorphic lithologies were identified and assigned to groups based solely on thin-section examination.

The petrographic characters of the sedimentary lithologies were described and supplemented by semiquantitative point counts and estimates of grain size. Lithologic grouping (Table 1) was according to criteria for composition, alteration, and compaction. Mineral identification was aided in some cases by scanning electron microscope (SEM) analysis of major element compositions (energy dispersive $x$-ray spectroscopy, EDS). Five sediment samples showing evidence of plant materials were submitted for palynological preparation (K. Weiss, Perth) and the isolated palynomorphs assemblages were identified by Dr. R. Helby (Macquarie University). Diatom assemblages were identified by Dr. D. Harwood (Ohio State University). We are extremely grateful to these people for their help.

\footnotetext{
${ }^{1}$ Barron, J., Larsen, B., et al., 1991. Proc. ODP, Sci. Results, 119: College Station, TX (Ocean Drilling Program).

2 Ocean Sciences Institute, University of Sydney (F05), N.S.W., Australia, 2006.

${ }^{3}$ C.R.P.G., 15, Rue N.D, des Pauvres, BP 20, 54501 Vandoeuvre Cedex, France (Present address: Research School of Earth Sciences, Australian National University, P.O. Box 4, Canberra, ACT, Australia, 2601).
}

The petrographic figures were made either in polarized light (PL) or with crossed polars (CP). Throughout the text, samples are identified by thin-section (e.g., ts47) and ODP sample numbers.

\section{Geological Setting}

Sites 739-743 are located on the outer continental shelf and upper continental slope of Prydz Bay, 100-200 km from the present edge of the Amery Ice Shelf and 70-250 km from the nearest coastline-that of eastern Prydz Bay (Fig. 1). In the present interglacial regime, icebergs drift over the drill sites. Although little is known of their origin, principal sources are probably the Amery Ice Shelf (Lambert Glacier) or glaciers entering the sea east and west of that huge ice flow. Glacial outflows close to the drill sites include the Sørsdal and Polar Record glaciers. In glacial periods, patterns of ice extent were probably very different, and grounded ice apparently extended out to central Prydz Bay (Hambrey et al., 1989). The major bathymetric features of the continental shelf in Prydz Bay can be interpreted in terms of the effects of grounded ice extension (Stagg, 1985): the configuration of deeps on the shelf suggests a broad flow of grounded ice from the Lambert Glacier into the bay, and inner-shelf deeps are attributed to past glacial scouring, perhaps from local glacial outflows such as the Sørsdal Glacier.

Ice erosion and transport of geologic materials from East Antarctica may have had a complex history through time and may have followed complicated spatial patterns. For example, weathered and superficial sediments would presumably have contributed more in the early stages of erosion (Hambrey et al., this volume). Some is known of the regional ice flow under present conditions (e.g., Drewry, 1983), but no information on flow patterns during glacial stages has been advanced. The base of the major ice flow-the Lambert Glacier-is locally $1.5 \mathrm{~km}$ below sea level (Fedorov et al., 1982). Even the small Sørsdal Glacier appears to have eroded to $750 \mathrm{~m}$ below sea level (Wellman and Williams, 1982). This paper is not concerned with details of ice erosion and transport processes or patterns, but provides evidence on the general ice provenance over Sites 739-743. Thus, the clast contents of the waterlain and lodgement tills (see Hambrey et al., 1989) have not been distinguished.

Information on the distribution and characteristics of geological units in East Antarctica is available in Mond (1972), Grew (1982), Oliver et al., (1982), Tingey (1982), Harley (1987), Sheraton and Black (1988), Stuwe et al. (1989), Hambrey et al. (1989), and McKelvey and Stephenson (1990). 
Table 1. Lithology and sample number.

\begin{tabular}{|c|c|c|c|}
\hline $\begin{array}{l}\text { Lithologic } \\
\text { group }\end{array}$ & Sample (cm interval) & $\begin{array}{l}\text { Thin-section } \\
\text { number }\end{array}$ & Comment $^{a}$ \\
\hline I & $\begin{array}{l}739 \text { C-55R-1, 134-135 } \\
739 \text { C-35R-2, 124-125 } \\
742 \mathrm{~A}-1 \mathrm{R}-3,52-55 \\
739 \mathrm{C}-35 \mathrm{R}-2,26-28\end{array}$ & $\begin{array}{r}3 \\
21 \\
47 \\
90\end{array}$ & $\begin{array}{l}\text { Barren of spore/pollen } \\
\text { Early Oligocene-late Eocene } \\
\quad \text { diatoms }\end{array}$ \\
\hline II & $742 \mathrm{~A}-20 \mathrm{R}-1,110-112$ & 55 & $\begin{array}{l}\text { Jurassic-Cretaceous spore/ } \\
\text { pollen }\end{array}$ \\
\hline IIIA & $\begin{array}{l}739 \text { C-13(?)R-1, 27-29 } \\
739 \text { C-16R-3, } 105-106 \\
739 \text { C-13R-2, 6-9 } \\
743 \text { A-12X-1, 5-10 }\end{array}$ & $\begin{array}{l}10 \\
31 \\
64 \\
89\end{array}$ & $\begin{array}{l}\text { Permian spore/pollen } \\
\text { Triassic spore/pollen }\end{array}$ \\
\hline IIIB & $\begin{array}{l}739 C-14 R-C C, 2-7 \\
739 C-45 R-C C, 4-7 \\
739 C-18 R-1,69-71\end{array}$ & $\begin{array}{r}6 \\
18 \\
25\end{array}$ & \\
\hline IIIC & $\begin{array}{l}739 \mathrm{C}-4 \mathrm{R}-2,28-29 \\
739 \mathrm{C}-47 \mathrm{R}-1,60-61 \\
739 \mathrm{C}-14 \mathrm{R}-3,22-24 \\
742 \mathrm{~A}-17 \mathrm{R}-1,148-150 \\
742 \mathrm{~A}-16 \mathrm{R}-1,92-95 \\
742 \mathrm{~A}-16 \mathrm{R}-1,12-14 \\
739 \mathrm{C}-41 \mathrm{R}-2,63-63\end{array}$ & $\begin{array}{r}2 \\
4 \\
5 \\
40 \\
45 \\
49 \\
72\end{array}$ & $\begin{array}{l}\text { ?Permian or younger spore/ } \\
\text { pollen }\end{array}$ \\
\hline IV & $\begin{array}{l}739 \mathrm{C}-16 \mathrm{R}-2,38-40 \\
739 \mathrm{C}-34 \mathrm{R}-5,30-31 \\
739 \mathrm{C}-17 \mathrm{R}-4,26-27 \\
739 \mathrm{C}-15 \mathrm{R}-1,72-75 \\
742 \mathrm{~A}-16 \mathrm{R}-1,0-7 \\
742 \mathrm{~A}-11 \mathrm{R}-1,23-24\end{array}$ & $\begin{array}{r}1 \\
8 \\
16 \\
39 \\
76 \\
85\end{array}$ & \\
\hline V & $\begin{array}{l}739 \mathrm{C}-38 \mathrm{R}-3,120-124 \\
742 \mathrm{~A}-30 \mathrm{R}-3,86-88 \\
742 \mathrm{~A}-17 \mathrm{R}-5,33-35\end{array}$ & $\begin{array}{r}9 \\
42 \\
84\end{array}$ & \\
\hline VI & $\begin{array}{l}739 C-35 R-4(? 3), 46-50 \\
739 C-34 R-4,63-64\end{array}$ & $\begin{array}{l}23 \\
35\end{array}$ & \\
\hline VII & $739 \mathrm{C}-35 \mathrm{R}-\mathrm{CC}, 45-46$ & & \\
\hline VIII & $\begin{array}{l}739 \mathrm{C}-38 \mathrm{R}-1,3-5 \\
739 \mathrm{C}-38 \mathrm{R}-1,148-150\end{array}$ & 60 & \\
\hline IX & $\begin{array}{l}739 \mathrm{C}-14 \mathrm{R}-1,107-108 \\
742 \mathrm{~A}-13 \mathrm{R}-1,8-10\end{array}$ & $\begin{array}{l}13 \\
46\end{array}$ & \\
\hline $\mathrm{x}$ & $\begin{array}{l}739 \mathrm{C}-34 \mathrm{R}-4,63-64 \\
739 \mathrm{C}-4 \mathrm{R}-1,131-133 \\
739 \mathrm{C}-48 \mathrm{R}-1,140-143 \\
739 \mathrm{C}-26 \mathrm{R}-3,53-55 \\
739 \mathrm{C}-29 \mathrm{R}-5,26-31 \\
739 \mathrm{C}-14 \mathrm{R}-1,107-108 \\
739 \mathrm{C}-4 \mathrm{R}-1,131-135 \\
739 \mathrm{C}-44 \mathrm{R}-2,107-109 \\
\text { 739C-28R-4, 31-32 } \\
\text { 742A-15R-2, 135-136 } \\
\text { 739C-43R-1, 1-4 } \\
\text { 739C-38R-3, } 146-147\end{array}$ & $\begin{array}{r}11 \\
7 \\
13 \\
33 \\
38 \\
37 \\
54 \\
63 \\
65\end{array}$ & \\
\hline $\mathrm{XI}$ & $\begin{array}{l}739 \mathrm{C}-38 \mathrm{R}-1,153-155 \\
739 \mathrm{C}-44 \mathrm{R}-1,12-14 \\
742 \mathrm{~A}-14 \mathrm{R}-2,45-46 \\
742 \mathrm{~A}-31 \mathrm{R}-3,40-42 \\
739 \mathrm{C}-16 \mathrm{R}-1,69-71 \\
739 \mathrm{C}-19 \mathrm{R}-3,30-34\end{array}$ & $\begin{array}{l}30 \\
22 \\
83 \\
59 \\
\\
34\end{array}$ & \\
\hline XII & $\begin{array}{l}\text { 739C-42R-1, 30-32 } \\
740 \mathrm{~A}-5 \mathrm{R}-\mathrm{CC}, 15-20 \\
\text { 739C-2H-1, 10-11 } \\
\text { 741A-4R-1, 15-20 } \\
\text { 742A-16R-1, 131-134 } \\
\text { 742A-10R-1, 17-20 } \\
742 \mathrm{~A}-3 \mathrm{R}-1,36-40 \\
739 \mathrm{C}-59 \mathrm{R}-1,44-45 \\
739 \mathrm{C}-33 \mathrm{R}-6,24-25\end{array}$ & $\begin{array}{l}41 \\
80 \\
73 \\
71\end{array}$ & \\
\hline XIII & $\begin{array}{l}\text { 742A-14R-3, } 80-82 \\
\text { 742B-27R-5, 108-110 } \\
\text { 742A-10R-3, 57-59 } \\
\text { 739C-5R-1, 83-85 } \\
\text { 740A-4R-CC, } 2-5 \\
742 A-13 R-1,20-22\end{array}$ & $\begin{array}{l}43 \\
52 \\
79 \\
19\end{array}$ & \\
\hline
\end{tabular}

Table 1 (continued).

\begin{tabular}{|c|c|c|c|c|}
\hline $\begin{array}{l}\text { Lithologic } \\
\text { group }\end{array}$ & Sample (cm interval) & $\begin{array}{l}\text { Thin-section } \\
\text { number }\end{array}$ & & Comment $^{\mathrm{a}}$ \\
\hline XIV & $\begin{array}{l}\text { 739C-23R-2, 56-60 } \\
\text { 739C-13R-1, 82-84 } \\
\text { 742A-13R-1, 78-80 } \\
\text { 742A-3R-1, 2-4 } \\
\text { 742A-11R-3, 24-26 } \\
\text { 739C-23R-2, 56-60 } \\
\text { 739C-46R-1, } 112-114 \\
\text { 739C-20R-2, 35-38 } \\
\text { 739C-36R-3, 51-55 } \\
\text { 739C-4R-3, 144-145 } \\
\text { 739C-21R-2, 144-146 } \\
\text { 739C-20R-3, 26-29 } \\
\text { 739B-1H-1, 90-92 } \\
\text { 739C-15R-1, } 142-143 \\
\text { 742A-8R-1, 6-9 } \\
\text { 742A-18R-1, 137-138 } \\
\text { 742A-14R-1, 5-10 } \\
\text { 742A-6R-1, 18-22 } \\
\text { 742A-16R-1, 96-98 } \\
\text { 742A-6R-1, 8-11 } \\
\text { 742A-15R-3, } 118-120 \\
\text { 739A-1H-2, 132-135 } \\
\text { 739C-55R-1, 52-54 } \\
\text { 739A-1H-2, 135-138 } \\
\text { 739C-60R-1, 25-26 } \\
\text { 739C-38R-2, } 114-117 \\
\text { 739C-18R-1, 60-62 }\end{array}$ & $\begin{array}{r}48 \\
50 \\
44 \\
36 \\
32 \\
28 \\
26 \\
27 \\
12 \\
14 \\
17 \\
24 \\
78 \\
87 \\
88 \\
58 \\
57 \\
56 \\
53 \\
6 \\
62 \\
66 \\
67 \\
68 \\
70\end{array}$ & $\begin{array}{l}\mathrm{Mc} \\
\mathrm{Mc} \\
\\
\mathrm{Mc} \\
\mathrm{Gnt} \\
\mathrm{Mc} \\
\mathrm{Mc} \\
\mathrm{Mc} \\
\mathrm{Mc} \\
\mathrm{Gnt} \\
\mathrm{Gnt}\end{array}$ & \\
\hline$x V$ & $\begin{array}{l}739 \mathrm{C}-41 \mathrm{R}-1,101-102 \\
742 \mathrm{~A}-11 \mathrm{R}-1,1-4 \\
742 \mathrm{~A}-9 \mathrm{R}-1,51-53\end{array}$ & $\begin{array}{l}20 \\
51 \\
82\end{array}$ & & \\
\hline
\end{tabular}

${ }^{\mathrm{a}} \mathrm{Mc}=$ potassic composition with microcline; $\mathrm{Gnt}=$ sodic and garnet bearing.

\section{PRINCIPAL LITHOLOGIC GROUPINGS}

\section{Sedimentary}

Group I. Diatom-Bearing Ferruginous Marls: Samples 119-739C-55R-1, 134-135 cm (ts3); 119-739C-35R-2, 124-125 $\mathrm{cm}$ (ts21); 119-742A-1R-3, 52-55 cm (ts47); and $119-739 C-35 R-2,26-28 \mathrm{~cm}$ (ts 90$)$

The typical lithology of group I (e.g., ts90; Pl. 1, Fig. 1) is a tan-colored, silty, siderite-goethite marl, usually without any mesoscopic structure, but samples have sporadic peloids and/or burrows (e.g., ts3; Pl. 1, Fig. 3). Although the carbonate is micritic in texture, petrographic and EDS analyses show that siderite predominates and that calcite contents are low $(<10 \%)$. The disseminated siliciclastic silt is quartz-rich compared with other facies represented in the clast collection (Fig. 2), suggesting a relatively mature provenance. The silt is also texturally well sorted. Some samples (e.g., ts90) are highly fossiliferous, with principally diatoms, silicoflagellates and ebridians, radiolarians, and sponge spicules. The assemblage is late Eocene-early Oligocene in age (see Appendix).

Classified in the same group is a silty, diatomaceous sedimentary pyrite, of which only one small specimen is known (ts21; Pl. 1, Fig. 2). Echinoderm remains are abundant in this sample, indicating a marine depositional environment. The fossil materials remain well preserved; the diatom frustules are hollow whereas the echinoderm remains retain their porous texture and crystal-domain structure.

Group I lithology is clearly marine and nonglaciogenic, with no evidence of unsorted diamictic fabrics or indeed any substantial clastic input. The significance of the ferruginous composition is not known. 


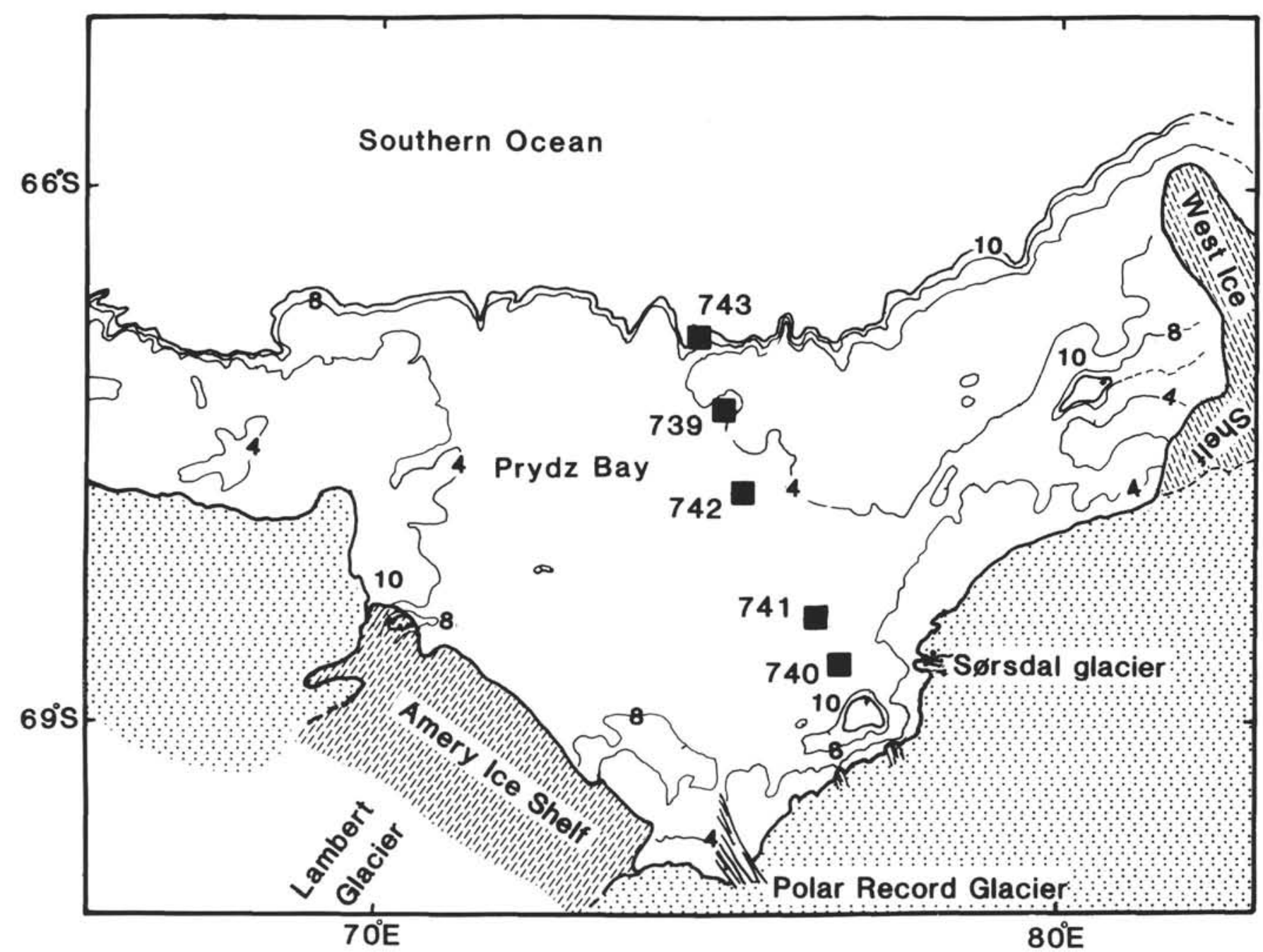

Figure 1. Location of Sites 739 through 743, the bathymetry of Prydz Bay, and the disposition of major glacial features. Contours in hundreds of meters.

Group II. Sandy Limestone: Sample 119-742A-20R-1, 110-112 $\mathrm{cm}(\mathrm{ts} 55)$

Sand and silt of quartz-feldspar composition lie in a matrix formed of micritic carbonate. The grains have a median size of $0.7 \mathrm{~mm}$ and a maximum of $5 \mathrm{~mm}$, and they appear to be "floating" in the carbonate matrix. Most are embayed, indicating a period of severe corrosion; petrographic relations suggest that this occurred during formation of the sediment. A small number of grains, however, retain well-rounded shapes.

The "clotted" structure that characterizes the intergranular carbonate results from varying fabric types in the micrite and probably also varying clay contents. Some clots may represent detrital carbonate sand grains with boundaries diagenetically obscured (e.g., Pl. 2, Fig. 1); median clot size is $0.75 \mathrm{~mm}$, with a maximum of $1.5 \mathrm{~mm}$. EDS analyses indicate that the carbonate is calcite with a small amount of magnesium present. A very common fabric in the clots (Pl. 2, Fig. 2) consists of 0.01-0.02mm-sized crystals with dark centers. It is not known whether the fabric characterizes any particular carbonate depositional process. In hand specimen the lithology shows no significant voids and is a pale grayish brown color.

The limestone, therefore, shows no features diagnostic of a particular sedimentary environment. However, a nonmarine sub- aerial setting would be consistent with the floating fabric of the clastic grains, their corrosion, and the clotted carbonate texture (Esteban and Klappa, 1983). Sample 119-742A-20R-1, 110-112 $\mathrm{cm}$ (ts55), contains Jurassic-Cretaceous pollen (see Appendix).

\section{Group III. Subarkosic, Plant-Bearing Sandstones and Siltstones}

The following form a natural sedimentary grouping in terms of composition, diagenesis, and texture.

Group IIIa. Carbonate-Altered, Plant-Bearing Subarkosic Sandstones and Siltstones: Samples 119-739C-13(?)R-1, 27-29 $\mathrm{cm}$ (ts10); 119-739C-16R-3, 105-106 cm (ts31); $119-739 C-13 R-2,6-9 \mathrm{~cm}$ (ts64); and $119-743 A-12 X-1,5-10 \mathrm{~cm}$ (ts89)

This facies includes principally sandstones and siltstones that have quartz, feldspar, mica, and plant material as the chief detrital components and a small amount of matrix composed of silt, clay, and/or carbonate and limonite. Extensive carbonate alteration to siderite has occurred in many of the clastic grains, and consequently, it is difficult to estimate the composition of the original clastic detritus. Only limited compaction has taken place; most quartz-feldspar grain contacts are straight and sutured contacts are rare. Although most grains are angular to 
C. J. JENKINS, C. ALIBERT

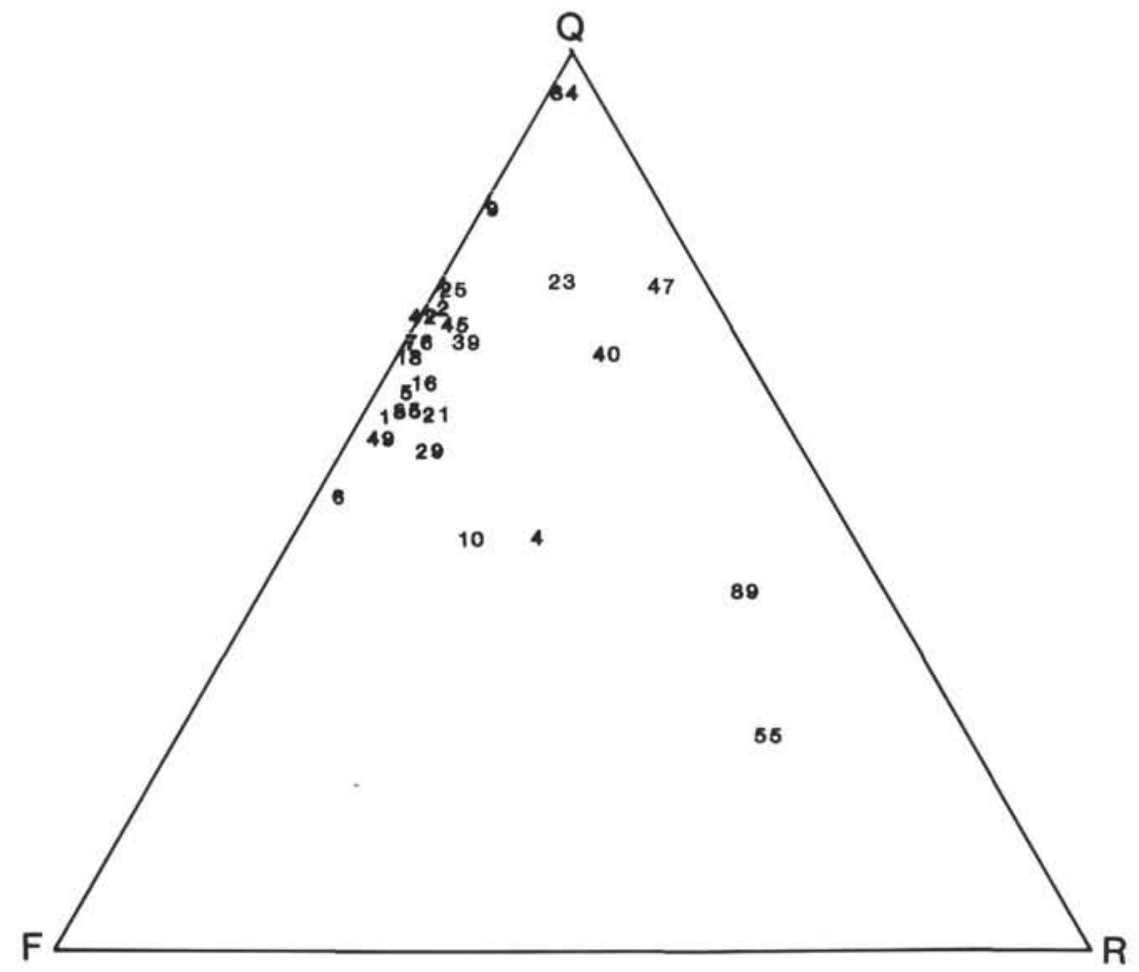

A

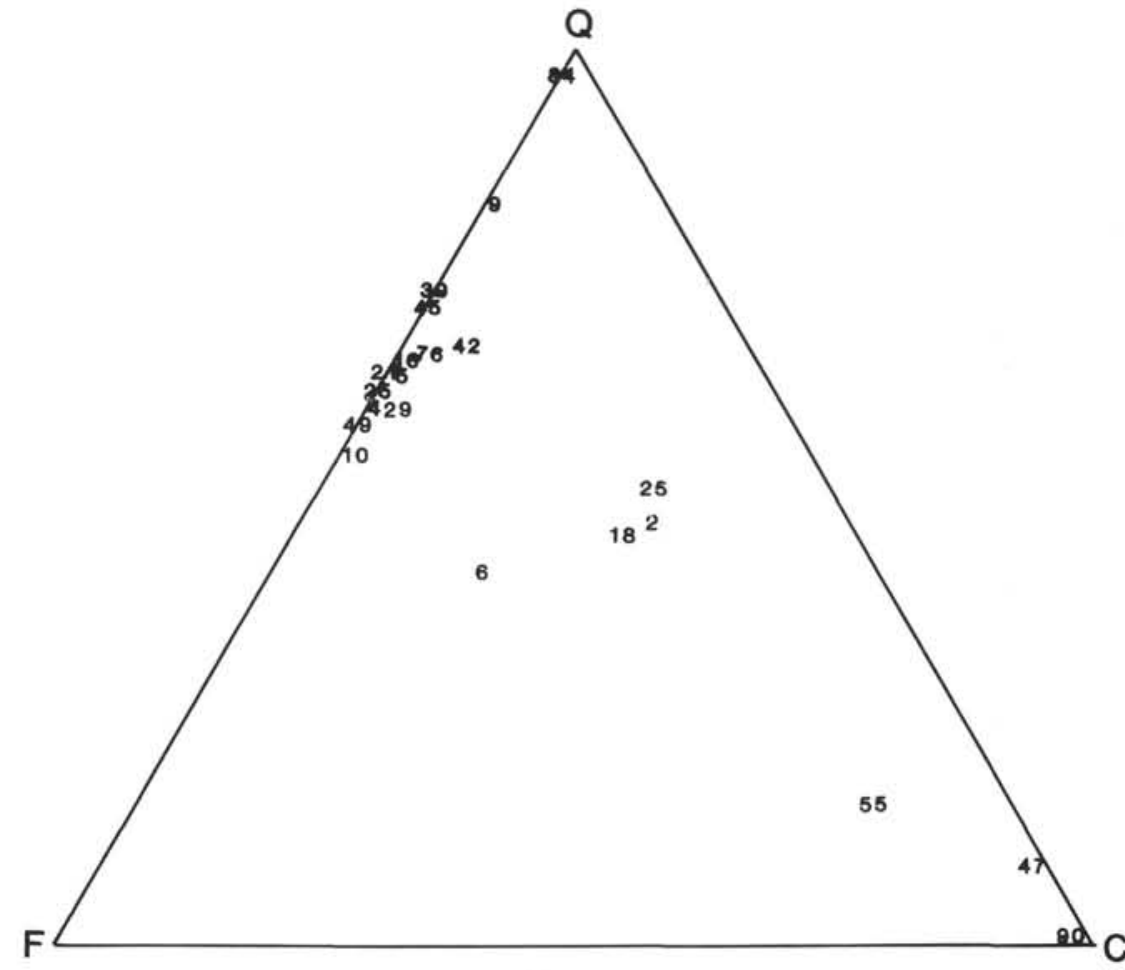

B

Figure 2. Petrographic point count compositional data for the sedimentary rocks. Numbers represent thin-section (ts) codes. A. Quartz-feldspar-rock (QFR); B. Quartz-feldspar-carbonate (QFC). 


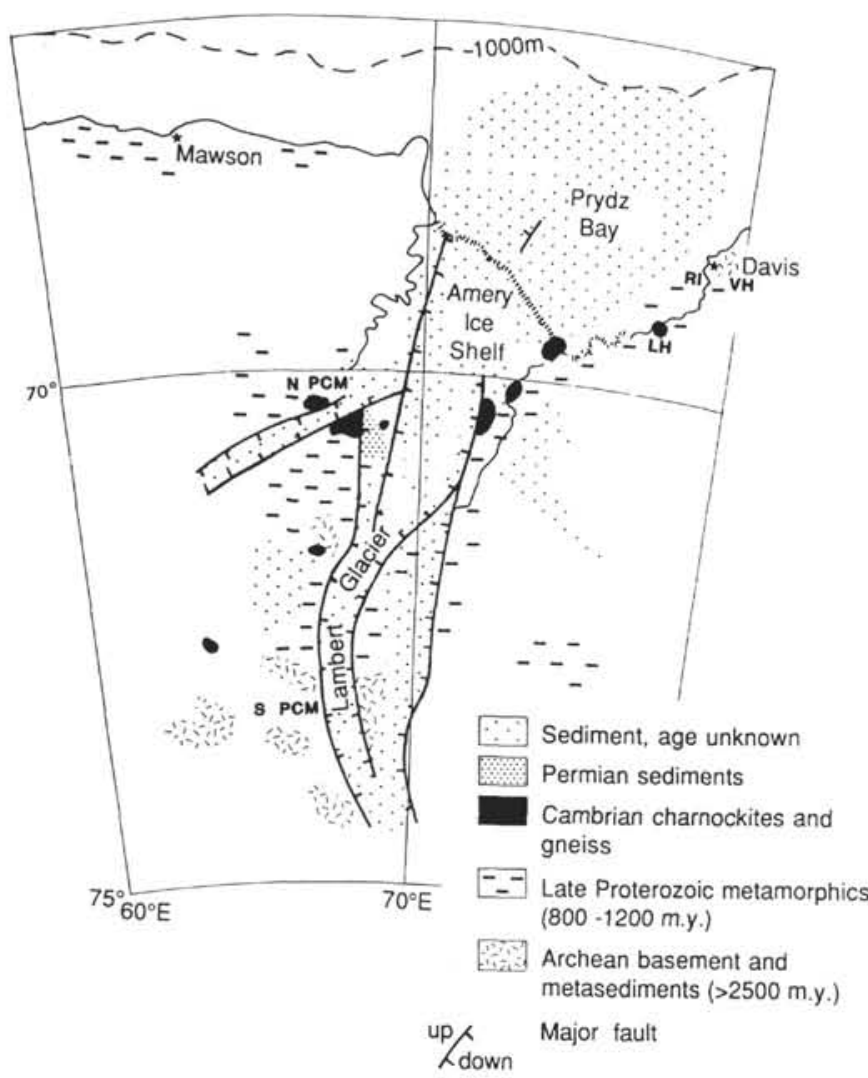

Figure 3. Regional geology of the Lambert Glacier-Prydz Bay region of East Antarctica (after Barron, Larsen, et al., 1989). N PCM = northern Prince Charles Mountains, S PCM = Southern Prince Charles Mountains, $\mathrm{LH}=$ Larsemann Hills, $\mathrm{VH}=$ Vestfold Hills, $\mathrm{RI}=$ Rauer Islands.

very angular, there are a few very well-rounded grains of quartz. The median grain size for the quartz-feldspar detritus is $0.3-0.1$ $\mathrm{mm}$, with a maximum of $0.6 \mathrm{~mm}$; the carbonate grains have a median of $0.5 \mathrm{~mm}$ and a maximum of $1.4 \mathrm{~mm}$. The siltstone phases are micaceous (to $11 \%$ ). The detrital quartz is of granitic (igneous-metamorphic) origin; polycrystalline quartz and feldspar (including microcline) are common.

The carbonate grains are free of contained quartz-feldspar detritus, present grain boundaries of detrital character, and are composed principally of siderite and minor calcite (petrographic and EDS analyses) with micrite and microspar textures. Most have a distinctively oriented, semiregular fabric of microspar crystals set in micrite. This is interpreted as a product of carbonate replacement of feldspar or mica. Rare patches of coarser microspar transect the finer structure of the grains.

Many specimens of this facies contain masses of opaque, black plant material. Commonly, a vesicular (cellular) structure suggests woody tissues, but some enclose quartzo-feldspathic silt (Pl. 2, Fig. 3)-implying a composite aggregation of once finely divided plant material. Sample 119-739C-13R-2, 6-9 cm (ts64), contained Permian palynomorphs, whereas Sample 119743A-12X-1, 5-10 cm (ts89), contained late Permian-Triassic palynomorphs (see Appendix).

Group IIIb. Well-Sorted, Carbonate-Cemented Sandstones: Samples 119-739C-14R-CC, 2-7 cm (ts6); 119-739C-45R-CC, 4-7 cm (ts18); and 119-739C-18R-1, 69-71 cm (ts25)

The lithology of group IIIb consists of texturally well-sorted, silty sand detritus of quartz-feldspar composition, set in a cal- careous matrix. Some samples appear to have had a grain-supported original structure. There is no evidence of significant lithologic compaction. In hand specimen, the lithology is pale gray in color and well lithified. The sand/silt grains are subangular to subrounded, and the median grain size is $0.6-0.7 \mathrm{~mm}$, with a maximum size of $2 \mathrm{~mm}$. The quartz, feldspar, and mica grains are commonly largely replaced by carbonate (e.g., PI. 2, Fig. 4). Accessory detrital minerals are in relatively high proportion in some samples (e.g., ts18) and include biotite, amphibole/pyroxene, zircon, and magnetite. Detrital coal grains are common, up to $1 \mathrm{~mm}$ in size, black, opaque, and well rounded; many contain siliciclastic silt. Intraclast grains of red-brown and gray claystone and of carbonate (after feldspar) are also present. Intergranular materials are predominantly carbonate (microspar or micrite), with a low proportion of clay.

Group IIIc. Subarkosic Micaceous Sandstones and Siltstones: Samples 119-739C-4R-2, 28-29 cm (ts2); 119-739C-47R-1, 60-61 cm (ts4); 119-739C-14R-3, 22-24 cm (ts5);

$119-742 A-17 R-1,148-150 \mathrm{~cm}$ (ts40); 119-742A-16R-1, 92-95 $\mathrm{cm}$ (ts45); 119-742A-16R-1, 12-14 cm (ts49); and $119-739 C-41 R-2,63 \mathrm{~cm}(t s 72)$

The rocks of this facies closely resemble those of lithologic group IIIa. However, detrital carbonate grains are not present, woody materials are rare, and mica (mostly biotite) is more abundant. The relative proportions of quartz-feldspar are similar (Fig. 2) and the extent of compaction is again slight; sutured grain contacts are uncommon. The biotite has almost always been altered to distinctively banded clay and iron oxide aggregations. Intergranular matrix and cement materials constitute a minor proportion of the rock and consist of clay with minor carbonate. Most specimens tend to be friable.

Sample 119-739C-41R-2, $63 \mathrm{~cm}$ (ts72), was found to contain ?Permian or younger palynomorphs.

\section{Group IV. Compacted Subarkosic Sandstones: Samples $119-739 C-16 R-2,38-40 \mathrm{~cm}$ (ts1); 119-739C-34R-5, 30-31 cm (ts8); 119-739C-17R-4, 26-27 cm (ts16); 119-739C-15R-1, 72-75 cm (ts39); 119-742A-16R-1, 0-7 cm (ts76); and $119-742 A-11 R-1,23-24 \mathrm{~cm}$ (ts85)}

In this lithologic group, sutured grain contacts are very common, indicating substantial lithologic compaction. The proportion of matrix/cement is small (about 10\%) but where present consists of clay and/or carbonate. Patches of microcrystalline quartz of diagenetic origin were also observed.

\section{Metamorphic}

The lithology classified here has undergone regional metamorphism, ranging from the imposition of foliation to anatexis. More extended lithologic descriptions are given in Barron, Larsen, et al. (1989, p. 452).

Group V. Quartzites: Samples 119-739C-38R-3, 120-124 cm (ts9); 119-742A-30R-3, 86-88 cm (ts42); and 119-742A-17R-5, $33-35 \mathrm{~cm}$ (ts84)

This lithology comprises highly lithified, fine sandstones of subarkosic composition, which are gray or pale yellow-brown in hand specimen. Virtually all quartz grain boundaries are sutured. The less abundant, scattered feldspars are altered to clays. Many feldspars have rounded grain outlines, which were rarely seen also for quartz grains. Mica (muscovite) is rare and no other accessory minerals were observed. Median grain size is $0.05-0.3 \mathrm{~mm}$, with a maximum of $0.2-0.5 \mathrm{~mm}$. Interstitial materials constitute less than $20 \%$ of the rock and appear to consist mainly of clays. 
Group VI. Metamorphosed Quartz-Siltstones: Samples $119-739 C-35 R-4(23), 46-50 \mathrm{~cm}$ (ts23); and 119-739C-34R-4, 63-64 cm (ts35)

These dark gray rocks are composed of quartz silt and lack feldspars or accessory detrital minerals. Median grain size is $0.075 \mathrm{~mm}$; maximum, $0.3 \mathrm{~mm}$. The quartz grain boundaries are highly sutured where in contact and are highly corroded where adjacent to the matrix. Uniformly scattered neomorphic growths of olive-brown amphibole (up to $0.1 \mathrm{~mm}$ in size) indicate metamorphism, and the matrix phyllosilicate flakes are oriented to form a weak foliation.

\section{Group VII. Banded Iron Formation: Sample 119-739C-35R-CC, $45-46 \mathrm{~cm}$}

Magnetite layers alternate with quartz-green biotite-sericite layers, with some microfolding. Zircon grains are common.

Group VIII. Fuchsite Quartzite: Samples 119-739C-38R-1, 3-5 $\mathrm{cm}$; and 119-739C-38R-1, 148-150 cm (ts60)

The quartzite is fine-grained with the characteristic green coloration. It may display varying degrees of deformation, including foliation.

Group IX. Mylonites: Samples 119-739C-14R-1, 107-108 cm (ts13); and 119-742A-13R-1, 8-10 cm (ts46)

Compositional variations include quartz-feldspar and sillimanite-quartz lithology.

Group X. Mica Schists: Samples 119-739C-34R-4, 63-64 cm; 119-739C-4R-1, 131-133 cm; 119-739C-48R-1, 140-143 cm; $119-739 C-26 R-3,53-55 \mathrm{~cm}$ (ts11); 119-739C-29R-5, 26-31 cm (ts 7); 119-739C-14R-1, 107-108 cm (ts13); 119-739C-4R-1, 131-135 cm (ts33); 119-739C-44R-2, 107-109 cm (ts38); $119-739 C-28 R-4,31-32$ (ts37); 119-742A-15R-2, $135-136 \mathrm{~cm}$ (ts54); 119-739C-43R-1, $1-4 \mathrm{~cm}$ (ts63); and 119-739C-38R-3, $146-147 \mathrm{~cm}$ (ts65)

Quartz and biotite are dominant, with amphibole, epidote, sillimanite, muscovite, and accessory minerals (zircon, magnetite, tourmaline, and dumortierite). The schists are well foliated.

Group XI. Amphibolites: Samples 119-739C-38R-1, 153-155 cm (ts30); 119-739C-44R-1, 12-14 cm (ts22); 119-742A-14R-2, $45-46 \mathrm{~cm}$ (ts83); 119-742A-31R-3, 40-42 cm (ts59); $119-739 C-16 R-1,69-71 \mathrm{~cm}$; and $119-739 \mathrm{C}-19 \mathrm{R}-3,30-34 \mathrm{~cm}$ (ts34)

Typical and atypical varieties are represented, the latter with quartz, carbonate, or garnet present.

Group XII. Granulitic Paragneisses: Samples 119-739C-42R-1, $30-32 \mathrm{~cm} ; 119-740 \mathrm{~A}-5 \mathrm{R}-\mathrm{CC}, 15-20 \mathrm{~cm} ; 119-739 \mathrm{C}-2 \mathrm{H}-1,10-11$ cm; 119-741A-4R-1, 15-20 cm; 119-742A-16R-1, 131-134 cm; $119-742 A-10 R-1,17-20 \mathrm{~cm}$ (ts41); 119-742A-3R-1, 36-40 cm (ts80); 119-739C-59R-1, 44-45 cm (ts 73); and 119-739C-33R-6, $24-25 \mathrm{~cm}$ (ts 71$)$

This suite contains gneisses with garnet, biotite, and sillimanite. Cordierite or hercynite are also represented in some examples (e.g., Samples 119-742A-16R-1, 131-134 cm, and 119$742 \mathrm{~A}-3 \mathrm{R}-1,36-40 \mathrm{~cm}$ [ts80]). Metamorphic layering and reaction textures are strongly expressed.

Group XIII. Mafic Gneisses: Samples 119-742A-14R-3, 80-82 cm (ts43); 119-742B-27R-5, 108-110 cm (ts52);

$119-742 A-10 R-3,57-59 \mathrm{~cm}$ (ts 79); 119-739C-5R-1, 83-85 cm (ts 19); 119-740A-4R-CC, 2-5 cm; and 119-742A-13R-1, 20-22 $\mathrm{cm}$

This class embraces well-layered clinopyroxene and two pyroxene gneisses, with the additional minerals biotite, garnet, amphibole, magnetite, feldspars, and quartz.
Group XIV. Granite Gneisses: Samples 119-739C-23R-2, $56-60 \mathrm{~cm} ; 119-739 C-13 R-1,82-84 \mathrm{~cm} ; 119-742 A-13 R-1,78-80$ cm (ts48) (Mc); 119-742A-3R-1, 2-4 cm (ts50) (Mc); $119-742 A-11 R-3,24-26 \mathrm{~cm}$ (ts 44); 119-739C-23R-2, 56-60 cm (ts36); 119-739C-46R-1, 112-114 cm (ts32); 119-739C-20R-2, $35-38 \mathrm{~cm}$ (ts28); 119-739C-36R-3, $51-55 \mathrm{~cm}$ (ts26) (Mc); $119-739$ C-4R-3, 144-145 cm (ts27); 119-739C-21R-2, 144-146 cm (ts12) (Gnt); 119-739C-20R-3, 26-29 cm (ts14) (Mc); $119-739 B-1 H-1,90-92 \mathrm{~cm}$ (ts17); 119-739C-15R-1, 142-143 cm (ts24) (Mc); 119-742A-8R-1, 6-9 cm (ts78) (Mc);

119-742A-18R-1, 137-138 cm (ts87); 119-742A-14R-1, $5-10 \mathrm{~cm}$ (ts88) (Mc); 119-742A-6R-1, 18-22 cm (ts58) (Gnt);

119-742A-16R-1, 96-98 cm (ts57) (Gnt); 119-742A-6R-1, 8-11 cm (ts56); 119-742A-15R-3, 118-120 cm (ts53);

$119-739 A-1 H-2,132-135 \mathrm{~cm}$ (ts61); 119-739C-55R-1, 52-54 cm (ts62); 119-739A-1H-2, 135-138 cm (ts66);

$119-739$ C-60R-1, 25-26 cm (ts67) (Mc); 119-739C-38R-2,

$114-117 \mathrm{~cm}$ (ts68) (Gnt); 119-739C-18R-1, 60-62 cm (ts70)

This group is a class of metamorphic lithology with quartz, biotite, green amphibole, \pm epidote, magnetite, sillimanite, and $\mathrm{K}$-feldspar plus a range of accessory minerals. Compositions are variable from potassic (with microcline; sample code "Mc") to sodic and garnet-bearing ("Gnt").

Group XV. Charnockitic Granite Gneisses: Samples $119-739 C-41 R-1,101-102 \mathrm{~cm}$ (ts20); 119-742A-11R-1, $1-4 \mathrm{~cm}$ (ts51); and 119-742A-9R-1, 51-53 cm (ts82)

Group XV consists of coarse-grained, slightly foliated rocks composed of orthopyroxene, quartz, and feldspars with accessory minerals zircon and magnetite.

\section{CONCLUSIONS}

\section{Sedimentary Units}

Two new sedimentary units were detected:

1. The diatom-bearing ferruginous marls (group I) represent a period of nonglaciogenic, marine, significantly biogenic deposition in the early Oligocene-late Eocene. Directly corresponding units were not cored by Leg 119 drilling, though comparable early Oligocene diatom assemblages (Bauldauf and Barron, this volume) were encountered in some of the diamictons and enclosed in shells in the diamicton. The lithology represents a phase of pre- or interglacial sedimentation, possibly older than the diatom-bearing in-situ strata recovered by Leg 119 drilling in Prydz Bay.

2. A unit of Jurassic-Cretaceous age, the sandy limestone (group II), appears to represent a period of nonmarine carbonate deposition and diagenesis-probably within the Prydz Bay Mesozoic sequence, which was incompletely sampled at Sites 740 and 741 (Barron, Larsen, et al., 1989).

The other sedimentary lithologic groupings apparently correlate with units that have previously been mapped in outcrop (Fig. 3): the quartzites (group V) and metamorphosed quartz siltstones (group VI) to the upper Archean sediments of the Southern Prince Charles Mountains, the banded iron formation (group VII) to outcrops in the Southern Prince Charles Mountains, and the subarkosic plant-bearing sandstones and siltstones (group III), in their various states of compaction and carbonate contents, to the late Permian-Triassic Amery Group of the Northern Prince Charles Mountains.

\section{Ice Provenance}

1. The Permian-Triassic subarkosic sandstones (groups III and IV) are well represented, comprising $12 \%$ of the entire clast collection. Rocks of similar age are exposed in the Beaver Lake area, Northern Prince Charles Mountains (Mond, 1972; Tingey, 
1982; McKelvey and Stephenson, 1990), consistent with a Lambert Glacier ice provenance. It is possible that similar rocks underlie the Lambert Glacier.

2. Fuchsite quartzite (group VIII), banded iron formation (group VII), and low-grade metamorphic rocks (mica schists, group X; amphibolites, group XI) are, based on present outcrop knowledge, restricted to the Southern Prince Charles Mountains region (Tingey, 1982; Grew, 1982).

3. Orthopyroxene-bearing (charnockitic) granitic gneisses are well represented along the coastal areas of eastern Prydz Bay (Vestfold Hills, Rauer Islands, and Larsemann Hills; Harley, 1987; Sheraton and Black, 1988; Stuwe et al., 1989). However, such rocks also occur in the Prince Charles Mountains and may not be especially diagnostic of provenance. A similar situation may apply with the mylonites, which at present are recorded only from the Vestfold Hills (Oliver et al., 1982).

It should be noted that all classes of lithology encountered as clasts have been recorded previously in the regions surrounding Prydz Bay, and that it is not necessary to postulate dropstone deposition from distantly derived icebergs. On the other hand, we find some puzzling omissions from the lithology represented, such as the mafic intrusive rocks that are common throughout the Prince Charles Mountains (Mond, 1972; McKelvey and Stephenson, 1990) and Vestfold Hills and the cordierite-bearing ("blue") gneisses of the Vestfold Hills and Larsemann Hills (Stuwe et al., 1989; Harley, 1987). Although coal was not represented as actual clasts, disseminated coaly materials were present in the diamictons.

In terms of abundance, the stratigraphic distribution of clast lithology appeared mostly uniform, though the group III sedimentary lithology that probably represents the Permo-Triassic sequences reaches peak abundance at the level of Cores 119. 739C-13R to 119-739C-18R (early Pliocene-late Miocene; Barron, Larsen, et al., 1989) and 119-742A-16R (?Pliocene).

To summarize, clast compositions for the glacial diamictons drilled at ODP Sites 739 to 743 are consistent with the ice supply dominantly from the Lambert Glacier. No compelling evidence was found for even a minor supply from the nearby coastline areas of the Vestfold Hills and Larsemann Hills.

\section{REFERENCES}

Barron, J., Larsen, B., et al., 1989. Proc. ODP, Init. Repts., 119: College Station, TX (Ocean Drilling Program).

Drewry, D. J., 1983. Antarctica: Glaciological and Geophysical Folio, Sheet 2, The Surface of the Antarctic Ice Sheet: Cambridge (Scott Polar Institute).

Esteban, M., and Klappa, C. F., 1983. Subaerial exposure environment. In Scholle, P. A., Bebout, D. G., and Moore, C. H. (Eds.), Carbonate Depositional Environments. AAPG Mem., 33:2-54.

Fedorov, L. V., Grikurov, G. E., Kurinin, R. G., and Masolov, V. N., 1982. Crustal structure of the Lambert Glacier area from geophysical data. In Craddock, C., Loveless, J. K., Vierima, T. L., and Crawford, K. (Eds.), Antarctic Geoscience: (Univ. Wisconsin Press), 931-936.

Grew, E. S., 1982. Geology of the Southern Prince Charles Mountains, East Antarctica. In Craddock, C., Loveless, J. K., Vierima, T. L., and Crawford, K. (Eds.), Antarctic Geoscience: Madison (Univ. Wisconsin Press), 473-478.

Hambrey, M. J., Larsen, B., Ehrmann, W. U., and ODP Leg 119 Shipboard Scientific Party, 1989. Forty million years of Antarctic glacial history yielded by Leg 119 of the Ocean Drilling Program. Polar Rec., 25:99-106.

Harley, S. L., 1987. Precambrian geological relationships in high-grade gneisses of the Rauer Islands, East Antarctica. Aust. J. Earth Sci., 34:175-207.

Kemp, E. M., Balme, B. E., Helby, R. J., Kyle, R. A., Playford, G., and Price, P. L., 1977. Carboniferous and Permian palynostratigraphy in Australia and Antarctica: a review. Bur. Min. Res. J. Aust. Geol. Geophys, 2:177-208.
McKelvey, B. C., and Stephenson, N.C.N., 1990. A geological reconnaissance of the Radok Lake area, Amery Oasis, Prince Charles Mountains. Antarc. Sci., 2:53-66.

Mond, A., 1972. Permian sediments of the Beaver Lake Area, Prince Charles Mountains. In Adie, R. J. (Ed.), Antarctic Geology and Geophysics: Oslo (Universitetsforlaget), 585-589.

Oliver, R. L., James, P. R., Collerson, K. D., and Ryan, A. B., 1982. Precambrian geologic relationships in the Vestfold Hills, Antarctica. In Craddock, C. (Ed.), Antarctic Geoscience: Madison (Univ. Wisconsin Press), 435-444.

Sheraton, J. W., and Black, L. P., 1988. Chemical evolution of granitic rocks in the East Antarctic Shield, with particular reference to postorogenic granites. Lithos, 21:37-52.

Stagg, H.M.J., 1985. The structure and origin of Prydz Bay and MacRobertson Shelf, East Antarctica. Tectonophysics, 114:315-340.

Stuwe, K., Braun, H.-M. and Peer, H., 1989. Geology and structure of the Larsemann Hills area, Prydz Bay, East Antarctica. Aust. J. Earth Sci., 36:219-241.

Tingey, R. J., 1982. The geologic evolution of the Prince Charles Mountains-an Antarctic Archean cratonic block. In Craddock, C. (Ed.), Antarctic Geoscience: Madison (Univ. of Wisconsin Press), 455464.

Wellman, P., and Williams, J. W., 1982. The extent of Archean and late Proterozoic rocks under the ice cap of Prince Elizabeth Land. BMR J. Aust. Geol. Geophys, 7:217-228.

Date of initial receipt: 14 December 1989

Date of acceptance: 6 June 1990

Ms 119B-127

\section{APPENDIX}

\section{Paleontological Data}

A summary of the paleontological findings of Dr. D. Harwood for diatoms and Dr. R. Helby for palynology.

\section{GROUP I}

Sample 119-739C-35R-2, 26-28 cm (ts90)

Diatoms: Actinoptychus senarius, Hemiaulis caracteristicus, $H$. disimilis, H. polycystinorum, Pyxilla reticulata group, Sceptroneis lingulatus, Stephanopyxis grunowii, S. splenidus (veg. and spores), S. turris, Stellarima spp. Ebridians: Rhizosolenia spp. Silicoflagellate: Dictyocha deflandrei. Late Eocene-early Oligocene, ?36-34 Ma.

$$
\text { Sample 119-742A-1R-3, 52-55 cm (ts47) }
$$

Essentially barren of palynomorphs.

\section{GROUP II}

$$
\text { Sample 119-742A-20R-1, 110-112 cm (ts55) }
$$

Moderate organic yield, very rare palynomorphs; Callialasporites dampieri identified, range Jurassic-Cretaceous.

\section{GROUP III}

Sample 119-739C-13R-2, 6-9 cm (ts64)

Moderate organic yield, meager palynological component (preservation poor to fair). Permian, unlikely to be older than stage 4 of Kemp et al. (1977).

$$
\text { Sample 119-743A-12X-1, 5-10 cm (ts89) }
$$

Moderate organic yield with very meager palynomorph component (preservation poor to very poor). Probable Falcisporites microflora, Triassic.

\section{GROUP IIIc}

$$
\text { Sample 119-739C-41R-2, } 63 \mathrm{~cm} \text { (ts72) }
$$

Extremely meager palynomorph yield; ?bisaccate pollen present, suggesting Permian or younger. 

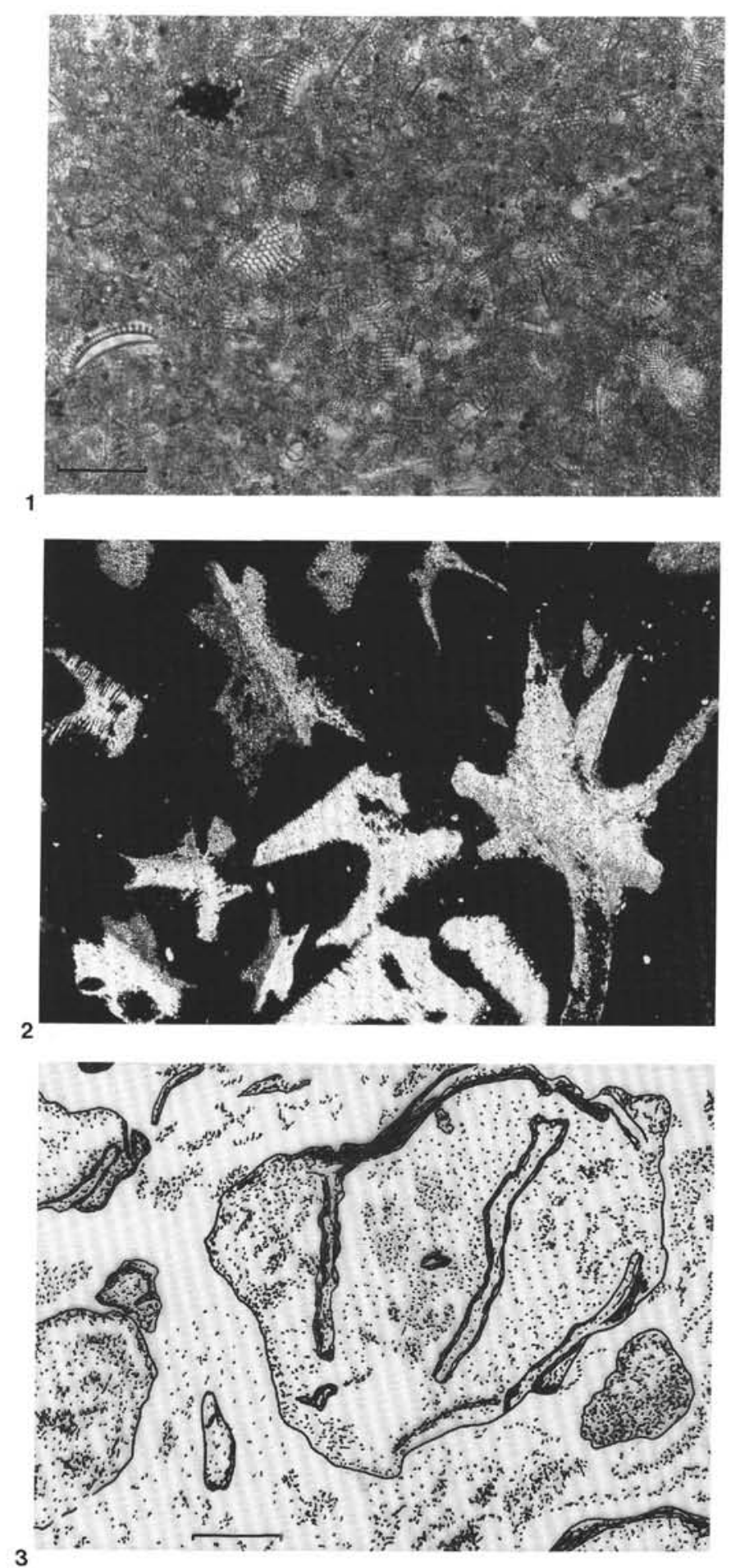

Plate 1. Petrographic sections of the diatom-bearing ferruginous marl (group I) clasts. 1. Diatomaceous siderite-goethite marl, late Eocene-early Oligocene; Sample 119-739C-35R-2, 26-28 cm (ts90), PL; 0.05-mm bar. 2. Echinoderm remains in sedimentary pyrite, late Eocene-early Oligocene; Sample 119-739C-35R-2, 124-125 cm (ts21), CP; 0.5-mm bar. 3. Burrowed peloidal structures from siderite-goethite marl; Sample 119-739C-55R-1, 134-135 cm (ts3); PL; 0.5-mm bar. 

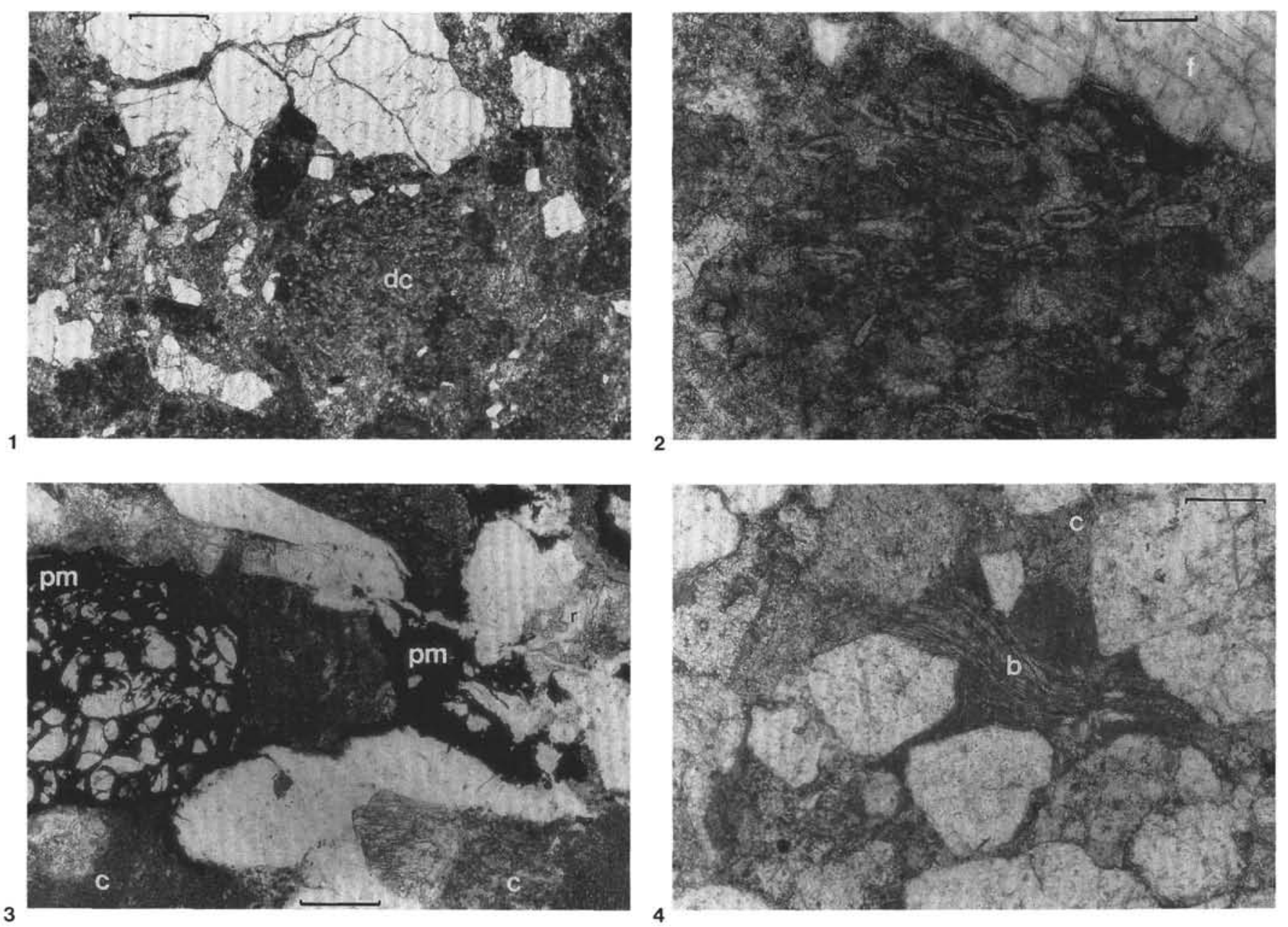

Plate 2. Petrographic sections. 1 and 2. Sandy limestone (group II), Jurassic-Cretaceous. Note the fracturing and corrosion of large quartz-feldspar grains and the ill-defined detrital grains of micritic/microspar carbonate (dc), shown in detail in Figure 2. Sample 119-742A-20R-1, 110-112 cm (ts55); PL; 1. 0.5-mm bar, 2. 0.1-mm bar. 3. Carbonate-altered, plant-bearing subarkosic sandstone (group IIIa), Triassic. Plant material (pm) forms are (1) silt/carbonate bearing and blocky and (2) pure, interstitial, and deformed. Note carbonate replacement ( $r$ ) of quartz and the abundance of large grains of micritic carbonate (c). Sample 119-743A-12X-1, 5-10 cm (ts89); PL; 0.1-mm bar. 4. Carbonate-cemented subarkosic sandstone (group IIIb), ?Permian-Triassic. Note compactionally deformed biotite (b) and quartz-feldspar grains altered to carbonate and interstitial micritic-microspar carbonate; Sample 119-739C-18R-1, 69-71 cm (ts25); PL; 0.25-mm bar. 